\title{
Challenges and Opportunities of Small-Scale Irrigation Practice in Abay Chomen District of Oromia National Regional State, Ethiopia
}

\author{
Temesgen Hirko ${ }^{1 *} \quad$ Mengistu Ketema ${ }^{2} \quad$ Fekadu Beyene $^{3}$ \\ 1.Department of Agricultural Economics, College of Agriculture and Natural Resources, Wolkite University, \\ Wolkite, Ethiopia \\ 2.Department of Agricultural Economics, College of Agriculture and Environmental Sciences, Haramaya \\ University, Haramaya, Ethiopia \\ 3.Department of Rural Development, College of Agriculture and Environmental Sciences, Haramaya University, \\ Haramaya, Ethiopia
}

\begin{abstract}
Ethiopian economy is highly dependent on agriculture which is dominated by traditional rain-fed small-scale farmers. The government is working on irrigation development giving special emphasis to research activities on irrigation at different scales. In this study, two-stage sampling technique was used to select 167 target respondents. The primary data were collected using an interview schedule and conducting focus group discussions and key informant interview. Various documents were reviewed to collect the secondary data. Moreover, different constraints related with lack of market access, topography associated with distance of land from water source, inadequate government support, and poor or nonexistent market linkage, poor irrigation water management and development were forwarded by the participants. To solve the problems and improve small-scale irrigation practice, the government, should attempt to hamper factors that hinder small-scale irrigation practice and enhance factors that initiates small-scale irrigation practice.
\end{abstract}

Keywords: Abay Chomen District, Challenges, Opportunities, Small-Scale Irrigation Practice

DOI: $10.7176 /$ RHSS/11-17-03

Publication date:September $30^{\text {th }} 2021$

\section{Introduction}

Agriculture is the backbone of Ethiopian Economy. But Ethiopian agricultural practice has been traditionally dominated for centuries by small-scale farmers and its performance has long been adversely affected by shortage of rain and water that left many to sustain their lives on famine relief support (Abebe et al., 2011). From the total production, about 97 percent of Ethiopia's food crops are produced by rain-fed agriculture, where as only $3 \%$ is from irrigated agriculture (FAO, 2015). Due to high dependency on rain-fed agriculture and other topographic and low adaptive capacity and other related factors, Ethiopia ranks the ninth most susceptible country in the world to natural disasters and weather-related shocks (Tongul and Hobson, 2013). But the small-scale irrigation (SSI) contributes to poverty alleviation by enhancing productivity which leads to an increase in income and promoting economic growth and employment (Garcia-Bolanos et al., 2011). Irrigation also changes the lives of the rural households by increasing their production and productivity. A rapid increase in the area covered by irrigation, especially small-scale water use, provide farmers with opportunities to raise output on a sustainable basis and contribute to the reliability of food supplies (FAO, 2012). This indicates that there should be new means of production through irrigation water application by smallholder farmers rather than strongly relying on rain-fed agriculture. Hence increasing the opportunity and reducing the hindrance to irrigation participation needs to be made because irrigation is one means by which agricultural production can be increased to meet the growing food demands in Ethiopia, since agriculture still plays a critical role in the economy.

The government of Ethiopia has placed great emphasis on the development of irrigation facilities so as to increase agricultural production and productivity. This may help farmers overcome the cost problem for modern irrigation construction and overcome the problem of shortage of moisture for production. In line with this goal, the government also has planned to undertake a medium and large scale irrigation study and designing activities and making them ready for concerned relevant stakeholders (NPC, 2015). This shows that the experts from universities and research institutions engaged in conducting research activities on participation in irrigation practice at different levels contributes to the success of this goal.

There are opportunities and challenges for small-scale irrigation development in Ethiopia. Ethiopia is a rich country in water resource and most of the time it is termed as a water tower of east Africa because of its abundant water resource availability (Adugna, 2014). It has a huge potential of water resource which accounts 122 billion meter cube annual surface runoff and 2.9 billion meter cube groundwater, though it is characterized by uneven spatial and temporal distributions (Tesfa and Tripathi, 2015). But Ethiopia is using a very little of its abundant water resource potential for irrigated agriculture (ATA, 2016). Besides the opportunities there are many challenges 
to use a little of its potential in Ethiopia. Some of these challenges as identified by Gebremedhin and Asfaw (2015) include: (1) inadequate awareness of irrigation water management, (2) inadequate knowledge on improved and diversified irrigation agronomic practices, (3) shortage of basic technical knowledge on irrigation pumps, drip irrigation system, sprinkler irrigations, surface and spate irrigation methods (4) scheme based approach rather than area/catchments based approach for the development of SSI Schemes, (5) inadequate baseline data and information on the development of water resources, (6) lack of experience in design, construction and supervision of quality irrigation projects, (7) low productivity of existing irrigation schemes, (8) inadequate community involvement and consultation in scheme planning, construction and implementation of irrigation development, (9) poor economic background of users for irrigation infrastructure development, to access irrigation technologies and agricultural inputs, where the price increment is not affordable to farmers.

The farmers in Abay Chomen district fails to produce when there is shortage of rainfall despite its plenty of water resource potential that can be applied to agriculture. The farmers in the study area, Abay Chomen district, has been affected by the extreme events of climate change such as drought, flood and hailstone that lead the farmers to crop failure in different years (DOoARD, 2016). But irrigation can change the life of rural households (Abebe et al., 2011) and this can help the farmers to overcome the problem of shortage of rainfall and crop failures due to hailstorm and flood. In addition to this, according to Dereje and Desalegn (2016), small-scale irrigation (SSI), both directly and indirectly, has a great impact on enhancing farmers' livelihoods through different dimensions, such as diversification of crops grown, as well as increased agricultural production, household income, but the challenges of irrigation practice in Abay Chomen district is not systematically assessed. Therefore the objective of this study is to analyze opportunities and challenges of small-scale irrigation practices in Abay Chomen district.

\section{Research Methodology}

\subsection{Description of the Study Area}

Abay Chomen District is one of the 9 districts in Horro Guduru Wollega zone of Oromia regional state of Ethiopia, containing 19 kebeles, located at $9^{\circ} 31^{\prime} 42^{\prime \prime}$ to $9^{\circ} 59^{\prime} 48^{\prime \prime} \mathrm{N}$ latitude and $37^{\circ} 10^{\prime} 03^{\prime \prime}$ to $37^{\circ} 28^{\prime} 44^{\prime \prime}$ E longitude and the capital of the district Fincha town is $289 \mathrm{kms}$ northwest of Addis Ababa. The District is bordered on the east by Ababo Guduru district, on the southeast by Guduru district, on the south by Fincha river, on the south west by the Jimma Geneti district, on the northwest by Amuru Jarte district and on the north by the Abay river which separates it from the Amhara region. The area receive high rainfall in one season of the year. The total area of the District is estimated to be $801.7 \mathrm{~km}^{2}$; approximately $45,37,4,3$ and $11 \%$ of the total area are cultivated land, noncultivated, water bodies, settlements, and woodlands and forests, respectively (Tegbaru, 2014).

The Ethiopian population projection by CSA for 2017, based on 2007 national census reported a total population for this district to be 64,672 , of whom 33,263 (51.43\%) were male and 31,409 (48.57\%) were female; 15,232 or $23.55 \%$ of its population were urban dwellers (CSA, 2013). The majority of the inhabitants were Protestant, (59.73\%), while 31.84\% reported Ethiopian Orthodox Christianity, 5.5\% reported their traditional beliefs, and $1.61 \%$ were Muslim (CSA, 2007).

The altitude of the study area ranges from 1,061 to 2,492 meters above sea level (masl) with two agro ecological zones, mid-highland and low land. The northern part of the district (low land), which is mainly situated at altitude ranging from 1,138 to 1,687 masl in the Nile River Basin, is owned by Fincha Sugar Factory and is entirely being used for irrigated sugarcane (Saccharum officinarum L.) production. At altitudes ranging from 2,213 to 2,492 masl (mid- highland), smallholder farmers practice mixed farming systems that integrate both crops and livestock (animals used for traction, meat and milk). These areas are under intensive cultivation and maize (Zea mays L.), teff (Eragrostis tef (Zucc.) Trotter), bread wheat (Triticum aestivum L.), niger seed (Guizotia abyssinica), barley (Hordeum vulgare L.) and faba bean (Vicia faba L.) are the major crops grown by rain-fed agriculture (CSA, 2013). Areas situated at altitude ranging from 1,061 to 1,138 and 1,687 to 2,213 masl are mainly woodlands and forests, and non-cultivated escarpments (Tegbaru, 2014).

The recent years meteorological data of the nearby representative stations, Fincha Sugar Factory and Shambu Meteorological Stations showed that the mean annual minimum and maximum temperatures of the district are 13.4 and $27.2{ }^{\circ} \mathrm{C}$, respectively, and the mean annual rainfall is $1,399 \mathrm{~mm}$ (Tegbaru, 2014). The area has a uni-modal rainfall pattern and the highest intensity of rainfall is recorded in the month of July. The area is characterized as hot to warm moist lowland and tepid to cool moist mid-highlands based on the classification of agro-ecological zones of Ethiopia (Alemayehu, 2006). 


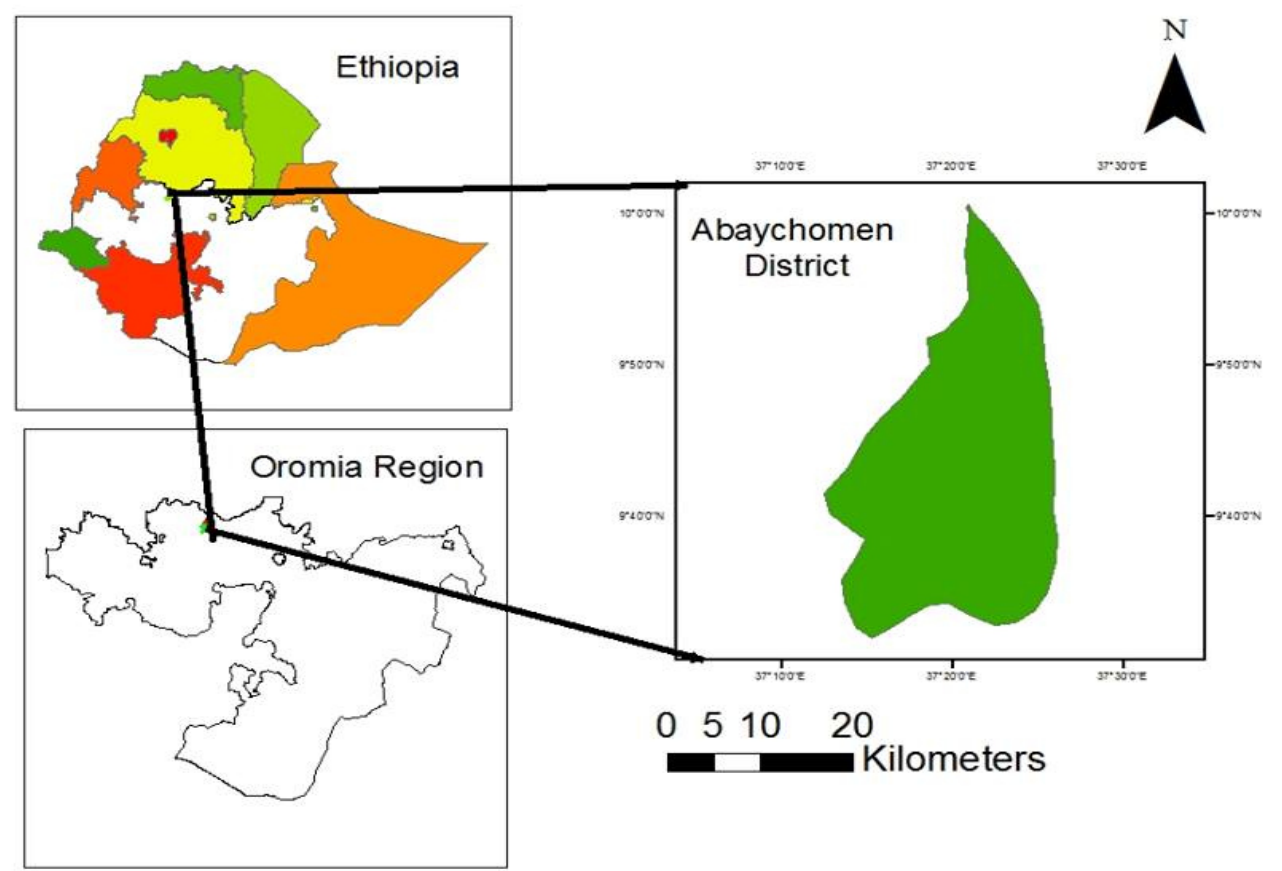

Figure 1. Location Map of Abay Chomen District, Oromia, Ethiopia

Source: Own design with the help of GIS expert

\subsection{Sampling Method and Sample Size}

The household was the basic sampling unit. In this study, a two-stage sampling technique was used to generate the required primary data. At the first stage, three kebeles from 16 non urban, mid-high land farmer kebeles in the district were selected randomly. On the second stage, by stratifying the households into participant and nonparticipant, a probability proportional to sample size sampling procedure was employed to select 167 sample households from which 80 participants and 87 non-participants were randomly selected, after preparing sample frame of participants and non-participants in the selected kebeles. But five observations (three participants and two non-participants) were excluded from the analysis due to missing values and 162 sample, 77 participants and 85 non-participants were used in the analysis. This sample size is assumed to represent the population, since the district is more or less homogeneous in terms of climate, resource endowment and other factors related to the issue of the study.

To determine the representative sample from the study area, the formula for sample size determination adjusting degree of precision to 0.07 due to shortage of resource, following Cochran (1977) has been used. And the sample size from each kebele was determined by proportionality formula.

Therefore, sample size is determined by formula (1).

$$
n=\frac{Z^{2} *(p)(q)}{d^{2}}
$$

Where $\mathrm{n}$ - sample size

$\mathrm{Z}$ - standard normal deviation (1.81 for $93 \%$ confidence level)

$\mathrm{P}=0.5$ (The proportion of the population participating in irrigation, that is $50 \%$ ) due to unknown variability $\mathrm{q}=1-\mathrm{P}=0.5(50 \%)$

$\mathrm{d}$ - desired degree of precision, $(0.07)$ in this case

\subsection{Types of Data, Data Sources and Methods of Data Collection}

For this study, both quantitative and qualitative data from primary and secondary sources were collected. The source for primary data was the sample farmers in Abay Chomen district and the source for secondary data are local offices, higher governmental organizations, different publications and policy documents. To obtain primary data, semi structured questionnaire, with both closed and open-ended questions was used as a tool to collect data from sample households. For the sake of conducting this study, important variables on economic, social and institutional factors related with the households in the study area were collected. For the purpose of getting data 
on the determinants of irrigation practice, the questionnaire covered a range of topics including demographic characteristics of households and socioeconomic structure; market access, access to credit, area of irrigated land, distance of farm land from water source, educational status, cultivable land size and other related factors were considered.

For the collection of primary data, enumerators, with at least secondary education that can speak local languages were recruited. Necessary care was taken in recruiting the enumerators. They were given an intensive training on data collection procedures, interviewing techniques and the detailed contents of the questionnaire. The households' questionnaire was translated in to local language (Afaan Oromoo), to convey the questions effectively to the rural interviewees and it was pre-tested, administered, filled by the trained and experienced enumerators. Strict supervision was made by the researcher during the course of the survey.

Secondary data were collected from documents and publications of different organizations and relevant local offices as well as journal documents. Moreover, available documents such as policies, strategies, guidelines and reports relevant to irrigation has been reviewed. In order to get relevant and detailed information about households' irrigation practice and its influencing factors in Abay Chomen district, focus group discussion and key informants interview was made in the study area. For both, focus group discussion and key informant interviews, unstructured interview (guiding question) was used as a tool of data collection.

Three focus groups, one from each selected kebeles consisting of 8 to 10 purposively selected farm household heads were used for collecting the detailed data using guiding questions and the district office of irrigation development coordinator and irrigation extension coordinator were interviewed considering them as key informants. These data were more of qualitative and they were used in supporting the quantitative data.

\subsection{Methods of Data Analysis}

Descriptive statistics and explorative method of data analysis has been used in this study. The test for descriptive values has been presented along with the calculated averages to show that there was a significant challenges on the small-scale irrigation practice in the study area.

\section{Results and Discussions}

\subsection{Descriptive Results}

\subsubsection{Types of Irrigation Used}

From the total participant sample households, the majority (78\%) uses the traditional river diversion (Table 5). Motor pump was the other irrigation type used by the farmers in the study area. There were about $9 \%$ of the participants that use motor pump irrigation. The lower number of the farmers use modern micro dam. This was the micro dam constructed by the Sustainable Land use and Management (SLM) project and the farmers around this project uses this modern micro dam irrigation. The other $10 \%$ of the participant households use other means of irrigation such as hand dug bucket watering and flood plain and draining wet lands.

Table 1. Distribution of sample households by the type of irrigation used for participants

\begin{tabular}{llll}
\hline Irrigation type & Frequency & Percent & Cumulative \\
\hline modern micro dam & 2 & 2.6 & 2.6 \\
traditional river diversion & 60 & 77.92 & 80.52 \\
motor pump & 7 & 9.09 & 89.61 \\
Others & 8 & 10.39 & 100.00 \\
\hline Total & 77 & 100.00 &
\end{tabular}

\subsubsection{Irrigated Land Size Per Household}

The average irrigated land size for the study area for the whole population was found to be 0.1892 ha which was less than the national average which has been previously estimated to lie between 0.25 to 0.5 ha per household (MoA, 2011). The standard deviation of this average for the total sample was higher than the mean irrigated land size, which indicates that there was high variation, because it includes the non-participants for which the irrigated land size was zero.

Table 2. Distribution of irrigated land size per household for participants and for all sample

\begin{tabular}{llllll}
\hline Variable & Obs & Mean & Std. Dev. & Min & Max \\
\hline Irrigated land size (All sample) & & & & & \\
Irrigated land size (Participants) & 162 & .1892 & .2999 & 0 & 2 \\
\hline Source: Ora & 77 & .398 & .326 & .125 & 2 \\
\hline
\end{tabular}

Source: Own computation from survey data, (2017)

The mean irrigated land size for the study area for the irrigators was found to be 0.398 ha and it was within the range of national average. The minimum and maximum irrigated land size for the participants was found to be 0.125 and 2 ha with the standard deviation of 0.326 ha which was less than the mean value which indicates that it was less varied than that of for the whole sample. 


\subsection{Challenges/Constraints and Opportunities in Small-Scale Irrigation Development in the Study Area}

There are many challenges and opportunities in the study area related to the small-scale irrigated farming. From the survey as well as key informant interview and focus group discussion it has been indicated that the farmers face many challenges in small-scale irrigation practice. Besides the challenges the data from different sources shown that there are opportunities for small-scale irrigation development. These Opportunities and challenges are discussed below.

\subsubsection{Challenges/Constraints}

Out of the challenges pointed out by the farmers, lack of market at the time of harvest holds the first rank. The farmers faces shortage of market demand at the time of harvest where prices are very low. This problem forced the farmers to sell their product at low price. There was no market linkage and this lead the farmers to be discouraged to participate in small-scale irrigated farming. The detail of the major challenges/constraints are discussed under this subsection.

The most critical challenge that was indicated in the study area by the focus group discussion as well as by the farmers interviewed was the problem of the topography of the farm land related with available irrigation water source (traditional diversion of surface water). Most of the farmers in the study area also indicated that they were unable to irrigate larger area of land because of difficulty to bring the water from surface water source by traditional river diversion. This problem has a high linkage with the distance of farm land from irrigation water source as surface water was the main source of irrigation water for the majority of the farmers and limited their participation and intensity of participation in small-scale irrigation.

The key informant interview figured out the following major constraints in the study area. These includes lack of knowledge on the efficient use of irrigation by the farmers. Not only the farmers, but also there was lack of trained man power on the irrigation technology and design. This lack of skilled man power lead to the loss of irrigation water when using in irrigated farming since it was dependent on traditional and less effective irrigation technologies such as totally earthen canals.

The lack of market and linkage to other market such as regional or national market was one of the major constraints in the study area. This lack of market lead the farmers not to participate in irrigated farming, or to irrigate lower area of land even if they are participants in irrigated farming.

The other problem pointed out by the key informants was lack of awareness on the sustainable use of water. This problem was inherently shown in the area that the conservation system of water resource was not carefully considered. This problem comes from the lack of knowledge on how to conserve and utilize this resource sustainably. The problem stems from the types of trees to be planted around the water sources and around the irrigated farming areas to use the water efficiently.

Lack of strong linkage between micro finance institutions and smallholder horticultural crop producers of the rural household was explained as it was very weak and it was pointed out as one of the other major constraints restraining the farm households to participate in irrigated farming. In addition to these challenges, as pointed out by key informants, there was no research to overcome the problems and research based extension systems are not adequate to improve the knowhow of the farmers and the development of irrigation systems.

\subsubsection{Opportunities}

There are opportunities that can help the farmers to be involved in irrigated farming at smallholder level as it was indicated by different sources of information such as sample respondents, focus group discussion and key informants. One of the major opportunities is the availability of surface water in the area. The district has many rivers such as Fincha, Amarti, Neshe, Gogoldas, Korke and many water streams flowing seasonally and throughout the year. Concerning the surface water, since many water streams are flowing throughout the year and high rainfall that can be stored and used for irrigation in the area, mini dams can contribute significantly for irrigating farm land in the area at many low leveled lands around the streams.

The other opportunity is that there is availability of favorable climate condition and ground water in the area. It can be used as an opportunity to produce more than once a year if the farmers could be able to access the ground water by means of treadle pump, hand pump and motor pump, even though the motor pump was indicated as costly both for buying and the energy required in terms of fuel. In the study area, the majority of the farmers indicated that the ground water would be more advantageous to practice small-scale irrigation on their farm land for participants and to increase the area of irrigated land and be benefited from the increase in the production that could be obtained from irrigation and hence increase their income and improve their standard of life. This does not only increase the farmers' standard of living but also contribute to overcome the problem of shortage of food in the other areas of the country if effective and efficient market linkage is created.

The other thing that can be taken as an opportunity for irrigation development in the study area is a great emphasis given for irrigation development by the government at country level. But the study area did not get any government support in terms of irrigation infrastructural development. The area has used more of the indigenous knowledge with little support from consultation of agricultural experts. Therefore, if the government give more support in terms of modern irrigation infrastructure, the study area would be more beneficial for its society as well 
as feeding the other areas and contributing to economic development of the country.

\section{Conclusion}

This study examined the challenges and opportunities of small-scale irrigation practice by the farm households in Abay Chomen district. The study used descriptive statistics and explanatory system of analyzing and presenting the data obtained from sample households and focus group and key informant interview concerning small-scale irrigation in the study area. The sample of 162 of the farm households selected by multi-stage sampling technique were used in the analysis excluding five samples with missing values.

\section{References}

Abebe Ejigu, Bihon Kassa and Gebremedhin Yihdego. 2011. Determinants of land allocation to irrigation and its wealth effect: Evidence from northern Ethiopia. Journal of the Drylands, 4(2): 310-319.

ADEA (Association for the Development of Education for Africa). 2014. Ethiopia Country Report For The 2014 Ministerial Conference On Youth Employment, Abidjan, Côte d'Ivoire, 21-23 July, 2014

Anonymous. n.d. Irrigation sector overview in Ethiopia.

DOoARD (Abay Chomen District Office of Agriculture and Rural Development). 2016. Annual Report on Rainfed and Irrigation Agriculture.

EEA (Ethiopian Economic Association). 2012. Annual Report on Ethiopian Economy. Addis Ababa, Ethiopia.

FAO (Food and Agricultural Organization). 2012. Comprehensive Africa Agriculture Development Programme, Corporate Document Repository.

FAO (Food and Agricultural Organization). 2015. Ethiopia Country Highlights on Irrigation Market Brief. UNFAO, Rome, Itally. Prepared under Food and Agricultural Organization of United Nations(UNFAO)/International Finance Corporation(IFC) cooperation.

Garcia-Bolanos, M., Borgia, C., Poblador, N., Dia, M., Seyid, O.M.V. and Mateos, L., 2011. Performance assessment of small irrigation schemes along the Mauritanian banks of the Senegal River. Agricultural water management, 98(7):1141-1152.

Kay, M. 2001. Smallholder irrigation technology: Prospects for Sub-Saharan Africa (No. 3). Food \& Agriculture Organization.

Makombe G., Regassa Namara, Fitsum Hagos, Seleshi Bekele, Mekonnen Ayana and Deborah Bossio. 2011. A comparative analysis of the technical efficiency of rain-fed and smallholder irrigation in Ethiopia (Vol. 143). International Water Management Institute.

MoARD (Ministry of Agriculture and Rural Development). 2010. Ethiopia's Agriculture Sector Policy and Investment Framework: Ten Year Road Map (2010-2020), Addis Ababa, Ethiopia.

Monenus Hundara. 2016. The impacts of hydropower projects in Ethiopia: The case of Fincha-Amarti-Nashe (FAN) project in Horo Guduru, western Ethiopia. Fribourg University.

Mwangi M. and Kariuki S. 2015. Factors Determining Adoption of New Agricultural Technology by Smallholder farmers in Developing Countries. Journal of Economic and Sustainable Development, 6(5): 208-216.

NPC (National Planning Commission). 2015. Ethiopian second five year (2015/16-2019/20) Growth and Transformation plan, Addis Ababa, Ethiopia

Tongul, H. and Hobson, M. 2013. Scaling Up an Integrated Watershed Management Approach through Social Protection Programmes in Ethiopia: The MERET and PSNP schemes. Hunger, Nutrition, Climate Justice. A New Dialogue: Putting People at the Heart of Global Development, 15-16 April 2013, Dublin, Ireland. 